\title{
sciendo
}

10.2478/aucft-2020-0024

\section{CHARACTERISTICS OF TECHNOLOGICAL PROPERTIES OF GRAIN AND FLOUR FROM ANCIENT VARIETIES OF WHEAT (EINKORN, EMMER AND SPELT)}

- Research paper -

\author{
Justyna BELCAR ${ }^{1 *}$, Anna SOBCZYK ${ }^{* *}$, Magdalena SOBOLEWSKA $^{* * *}$, Sławomir \\ STANKOWSKI***, Józef GORZELANY****
}

\author{
*Farming Cooperative SAN, Ląka 598, 36-004 Ląka, Poland; \\ ** Department of Food Technology and Human Nutrition, Collegium of Natural Sciences, University \\ of Rzeszow, Zelwerowicza 4 St., 35-601 Rzeszow, Poland \\ **** Department of Agroengineering, Faculty of Environmental Management and Agriculture, West \\ Pomeranian University of Technology in Szczecin, Pope Pawła VI 3 St., $71-459$ Szczecin, Poland \\ ${ }^{* * * * *}$ Department of Food and Agriculture Production Engineering, Collegium of Natural Sciences, \\ University of Rzeszow, St. Zelwerowicza 4, 35-601 Rzeszów, Poland
}

\begin{abstract}
The study presents assessment of commodity characteristics of grains from ancient varieties of wheat (einkorn, emmer and spelt) in comparison to grains of the conventional wheat cultivar Arkadia. The findings related to the grain of einkorn and emmer were very similar, and far worse than those related to spelt grain; the latter were found with better ratings, sometimes even in comparison to the conventional wheat grain (e.g. the highest mass-weight density). Similar relationships were observed between the flours produced by milling the grains. Analysis of the indirect baking quality indicators showed that flours from einkorn and emmer can effectively be used for baking purposes, however they present low technological value. The flour from emmer wheat was found to be the poorest, which was confirmed e.g. by the low gluten number, gluten index, Zeleny's index, and high gluten spreadability. Spelt flour was found to present moderate technological value. Based on the results it can be concluded that by using adequate modification in the process of dough kneading and fermentation it will be possible to produce high quality baked goods from ancient wheat grains.
\end{abstract}

Keywords: einkorn wheat, emmer wheat, spelt, assessment of grain as a commodity, baking properties of flour

\section{INTRODUCTION}

Wheat occupies the largest farming areas globally and is the main food crop, besides maize and rice (FAOSTAT 2017). Its cultivation was initiated in the Neolithic period (approx. 10000 years BCE). The earliest varieties were einkorn wheat (Triticum monococcum) and emmer wheat (Triticum dicoccum). Approximately 8 - 9 thousand years ago, cultivation of spelt wheat (Triticum aestivum ssp. spelta) was started in Europe (Rachoń et al., 2011). Einkorn was grown in the areas of today's Turkey, Balkan countries, and in the region of Caucasus (Ertop, 2019). Grain of this variety is characterised by high contents of proteins, lipids (incl. unsaturated fatty acids), antioxidants and conjugated phenolic acids (Hidalgo and Brandolini, 2017). With the increasing knowledge of nutrition

Received: 25.09 .2020 .

Accepted in revised form: 25.10 .2020 and consumers' growing interest in relic crops, novel enhanced cultivars of einkorn have emerged and the area in which the crop is grown have increased (USA, Canada, countries of Northern Europe) (Hidalgo et al., 2019).

Emmer wheat was once mainly cultivated in the areas of the Near East and Israel and then spread to countries in the Mediterranean and North Africa. From the nutritional viewpoint the advantages of emmer wheat include the high content of protein in the grain, the desirable amino acid profile, high content of micronutrients and sweet nutty taste; as regards the agronomic characteristics - the crop is tolerant to abiotic and biotic stress (Christopher et al., 2018).

Spelt originally was grown in Asia (areas of todays' Iran, Iraq and Syria); from there it was brought to Europe. This was the basic cereal crop in the times of the Roman Empire. Saint Hildegard of Bingen, the Medieval precursor of contemporary dietetics,

${ }^{1}$ Corresponding author. E-Mail address: justyna.belcar@op.pl 
used spelt grain as the essential nutrient. Before the new, more productive wheat cultivars with superior technological quality emerged, spelt was one of the most popular subspecies, grown e.g. in Scandinavia, Germany, Switzerland and Poland. Spelt is an undemanding plant- in order to grow and produce good crop it does not need to be heavily treated with crop protection chemicals, it does not require fertilisation or good climate and soil conditions (Cacak - Pietrzak and Gondek, 2010). This wheat variety may be grown in mountainous areas and in poor soil. It can easily adjust to extreme environmental conditions (Sobczyk et al., 2017b). At present it is gaining in popularity because consumers are increasingly aware of the need to look for healthy food products with greater nutritional value. Spelt grain predominantly comes from organic farms located in Germany, Austria, Switzerland, Belgium, France, Italy and Poland (Rożnowski et al., 2015; Krawczyk et al., 2008a). Works are being continued to breed new spelt cultivars with better technological parameters (Krawczyk et al., 2008a).

The ancient wheat varieties, because of the hulled caryopses, pose significant difficulties during harvesting and processing. Before the technological process is started, it is necessary to release the grains from the glumes. In laboratory conditions this is done using a husker device, while farming enterprises for this purpose use hullers and adequately adjusted shellers. The course of the process depends on the equipment applied and the way the glume is affixed to the caryopsis (Cacak Pietrzak et al., 2013).

Technological parameters of wheat grain most importantly include protein content. This characteristic determines the way in which the wheat is used, because it indirectly reflects the level of gluten proteins (Krawczyk et al., 2008a). Protein content and gluten yield affect the quality of cerealbased products, including the volume and appearance of baked goods and brittleness of pasta. In quantitative and qualitative terms these two characteristics depend on the plant variety as well as agricultural technologies applied and environmental conditions existing during the vegetation period (Knapowski et al., 2015). The mean protein contents in spelt grain are greatly varied ranging from 12.5 to $19.5 \%$ (Sawicka and Krochmal-Marczak, 2012); similar protein contents are found in caryopses of einkorn and emmer wheat.

Quantity and quality of gluten mainly depend on gluten proteins - gliadin and glutenin, which affect viscoelasticity and rheological properties of the dough produced. Due to its high spreadability, gluten from the old varieties of wheat used in the dough does not form stable gluten networks which would retain carbon dioxide molecules, as a result low-volume bread is obtained. The dough made from einkorn, emmer, and spelt flour is characterised by high viscosity and plasticity, it is less flexible in comparison to the dough from common wheat flour (Krawczyk et al., 2008a; Sobczyk et al., 2017b; Degaonkar et al., 2005). An indirect method allowing to assess baking quality of flour involves measurement of wet gluten content and its spreadability. Gluten number (GN) is a combined parameter reflecting these two measures. This is a product of gluten content in the flour and gluten quality. It reflects the mechanical properties of wheat dough and its gas holding capacity. The gluten number approaching zero corresponds to poorer baking quality of the flour.

In recent years consumers are increasingly interested in products from old varieties of wheat, mainly from wholemeal flour, because of the growing awareness of the high nutritional value of these products. Einkorn flour is used in making pastries and pasta, and it may be added to bread (Hidalgo and Brandolini, 2017). Einkorn grain is used in production of various types of cereal foods, such as groats and products added to soups. Emmer grain can be used in such food products as bread, crackers, breakfast cereals and pasta. It may also be used as a substrate in production of functional beverages (Coda et al., 2011). The flour is used in production of small flatbread such as tortilla, naan, roti and chapatti (Christopher et al., 2018). Spelt flour may be added to bread to increase its nutritional value because of its contents of biologically active prebiotics (Kraska et al., 2019). It can be used in making crackers because the technology applied in production of these snacks does not require high contents and quality of gluten. Depending on the type of the crackers, the dough must be subjected to fermentation using either a biological or chemical method (Filipčev et al., 2013). Other products include cracker waffles whose prebiotic activity results from the use of inulin syrup in the production process (Kohajdovà and Karovičovà, 2008). The so-called "green" spelt, i.e. unripe grains, may be used in cooking as well. At that stage the starch in the caryopsis is not fully developed and the grain has high contents of minerals and protein.

The purpose of the study is to determine technological value of grains from ancient varieties of wheat, i.e. einkorn, emmer and spelt, and to assess possible use of milled products obtained from the grain in cooking technologies. 


\section{MATERIAL AND METHODS}

\section{Material}

The material selected for the study comprised grains of three ancient varieties of spring wheat, i.e. einkorn - a local cultivar, emmer - the cultivar Lemella and spelt - the cultivar Wirtas as well as flours obtained by milling these grains. These old cultivars of wheat were obtained as a result of a field experiment conducted in 2018 at the Agricultural Experiment Station in Lipnik $\left(53^{\circ} 41^{\prime} \mathrm{N}, 14^{0} 97^{\prime} \mathrm{S}\right)$, part of West Pomeranian University of Technology in Szczecin. The reference material comprised grain and flour from winter wheat of Arkadia cultivar, supplied by SAN Farming Cooperative. The grain was grown using conventional farming methods, and harvested in 2018 in the village of Studzian $\left(50^{\circ} 02^{\prime} 52^{\prime \prime} \mathrm{N}, 22^{0} 27^{\prime} 38^{\prime \prime} \mathrm{E}\right)$ in the Przeworsk District, the Podkarpackie Region.

\section{Analysis of commodity characteristics of grains}

The methodology included determination of moisture content in the grain using oven drying method (PN-EN ISO 712:2012), determination of 1000 grain weight (TGW) expressed as dry weight (Haber and Horubałowa, 1975), grains bulk density (PN-EN ISO 7971-3:2019-03), grain uniformity and plumpness (Haber and Horubałowa, 1975), glassiness and degree of hulling. Grain uniformity and plumpness were assessed using SteineckerVögl sorter; uniformity was assumed to be reflected by percent share of the grains remaining in the sieves, mesh size of 2.2 and $2.5 \mathrm{~mm}$ jointly or 2.5 and $2.8 \mathrm{~mm}$, depending on which total amount was greater after the material shaking. Plumpness was defined as the weight of the grains remaining in the sieves with mesh size of 2.5 and $2.8 \mathrm{~mm}$, expressed as a $\%$ relative to the sample weight. To measure glassiness, the grains were cut in Farinotom seedcutter from Sadkiewicz Instruments, and then the cross-sectional surface of endosperm was examined. The result was expressed as the number of grains with either rglassy endosperm (surface uniformly gray, with gloss) or half-glassy endosperm (surface predominantly dull, a shade from white to gray). The degree of hulling was based on the authors' own conception; app. $50 \mathrm{~g}$ grain samples were taken and divided (using tweezers) into the fraction of hulled grains and fraction of grains released from glumes. Subsequently, percent share of the hulled fraction in the total weight was calculated for each sample.

\section{Grain conditioning prior to milling}

After the grain of the ancient wheats was purified in a laboratory separator (SLN3 type form Pfeuffer company), the material was conditioned up to the moisture content of $13.5 \%$. The grain of Arkadia cultivar was characterised by $14.05 \%$ moisture content, hence it was not conditioned, but milled directly after it had been purified.

\section{Grain milling}

After the conditioning process was completed the grains were subjected to milling in Quadrumat Junior roller mill manufactured by Brabender; as a result, two main fractions were obtained: flour $F_{1}$ and bran $B_{1}$. The bran $B_{1}$ was again refined and sieved in Bran Duster from Brabender; the process produced additional flour fraction, i.e. high extraction flour $\mathrm{F}_{2}$ and bran $\mathrm{B}$.

\section{Physical and chemical parameters of the flours}

Granularity of the flours was examined using sieve analysis, based on the methodology described by Horubałowa and Haber (1975), with the use of a laboratory sifter, type SZ-1 from Sadkiewicz Instruments. Moisture content in the flour was assessed using oven drying method, in accordance with PN-EN ISO 712:2012. Ash content in the flour was assessed by means of combustion method, in Nabertherm muffle furnace set to a program gradually increasing the temperature and then retaining the sample for a specified period in the defined combustion temperature of $900^{\circ} \mathrm{C}$. The contents of total proteins and damaged starch were determined using near infrared spectrophotometer DA 7200 manufactured by Perten Instruments.

\section{Assessment of the flours for indirect baking quality indicators}

To determine how the flours can be used, they were assessed for the wet gluten content (PN-EN ISO 21415-1:2007), spreadability, gluten number (PNEN ISO 21415:2015-12), gluten index (ICC 1994, Standard Method No. 155.), sedimentation value according to Zeleny (ICC 1994 Standard Method No. 116/1) and Hagberg - Perten falling number (ICC 1995, Standard Method No. 107/1). Gluten index was identified using Perten Glutomatic. Zeleny sedimentation test was performed using equipment manufactured by Sadkiewicz Instruments. The falling number was measured with a dedicated apparatus from Perten Instruments.

\section{Statistical analysis}

The results were subjected to statistical analyses using Statistica 13.3. software developed by StatSoft. A one-way analysis of variance (ANOVA) with completely randomized design was applied, with significance level defined as $\alpha=0.05$, taking into account the specific characteristics of the grains and flours, relative to the wheat cultivar. The mean values were compared using Tukey HSD test. 


\section{RESULTS AND DISCUSSION}

By analysing physical properties of wheat grains, it is possible to indirectly determine their milling quality. Wheat grain of high milling quality should be characterised by high 1000 grain weight, density and uniformity. The relevant wheat grains were characterised by moisture content ranging from $10.09 \%$ in spelt wheat to $14.05 \%$ in Arkadia wheat (Table 1). The relatively low water content in the emmer grains $(11.52 \%)$, in combination with the hardness of these caryopses associated with their glassiness, contributed to their increased fragility and tendency to break, which posed a significant difficulty in the testing and milling processes.

Density of wheat grains mainly depends on environmental conditions during growth period and on the variety. Bulk density was practically the same in einkorn, emmer and common wheat of Arkadia cultivar (a range of $67.67-68.06 \mathrm{~kg}^{-1} \mathrm{hl}^{-1}$ ), it was however significantly higher in spelt wheat, amounting to $75.05 \mathrm{~kg} h l^{-1}$ (Table 1). Similar grain density values in spelt cultivars and strains were found by other researchers; Sobczyk et al. (2017a) showed values ranging from 68.0 to $77.6 \mathrm{~kg} \mathrm{hl}^{-1}$, Cacak-Pietrzak et al. (2013) reported a value of 72.8 $\mathrm{kg} \mathrm{hl}^{-1}$ and Krawczyk et al. (2008b) showed values between 72.3 and $78.5 \mathrm{kghl}^{-1}$. Dąbkowska (2009) investigated spring varieties of spelt and reported mean grain density in the range of 61.4-65.8 $\mathrm{kg} \mathrm{hl}^{-1}$. The rate of 1000 grain weight (TGW) depends on a number of factors, e.g. wheat variety, total precipitation during growth period, and adequate application of mineral fertilisers. A higher TGW corresponds to larger and more uniform grains, which results in lower losses in the milling process. The lowest TGW was found in the grains of emmer and einkorn (below $25 \mathrm{~g}$ d.w.). The mean TGW in the case of spelt amounted to $31.25 \mathrm{~g} \mathrm{~d} . \mathrm{w}$. , and in the common wheat to $38.83 \mathrm{~g}$ d.w. (Table 1.). Other studies focusing on spelt showed TGW values which visibly differed, relative to the cultivar. The lowest TGW, in the range of $26.9-32.9 \mathrm{~g}$, was reported by Dąbkowska (2009) for spring cultivars of spelt. Slightly higher TGW, on average amounting to $34.5 \mathrm{~g}$, was identified in the spelt wheat investigated by Cacak-Pietrzak et al. (2013). The spelt cultivars and strains examined by Sobczyk et al. (2017a) and Krawczyk et al. (2008b) produced particularly robust grains with TGW in the ranges of $39.5-47.4 \mathrm{~g}$ and $38.7-52.7 \mathrm{~g}$, respectively. Research in spelt wheat conducted by Waga et al. (2002) and Capuchova (2001) showed even higher values of TGW, comparable to the rate observed in common wheat, and amounting to 52-54 g. LackoBartošová and Rédlová (2007) reported similar TGW in spelt grains, in the range of 47.97-54.58 g. The low TGW values in einkorn and emmer were related to the uniformity and plumpness of the grains. As regards grain uniformity, there were statistically significant differences between all the wheat cultivars. The younger the cultivar, the more uniform grain was found (from $26.87 \%$ in einkorn to $92.65 \%$ in conventional wheat). Plumpness in the old wheat varieties was in the range of $62.43-$ $66.98 \%$, however the emmer grain did not differ visibly from einkorn and spelt, while the spelt grain was significantly larger than einkorn grain. The largest grains were produced by the common wheat (with plumpness of $92.65 \%$ ). In a study by Sobczyk et al., (2017a) uniformity of spelt grain amounted to $77 \%$. Similar findings related to this variety were shown by Cacak-Pietrzak and Gondek (2010) who reported mean uniformity of $76 \%$ and plumpness of $64 \%$.All the ancient wheat varieties in question belong to unthreshable cereals. Compared to the common wheat, the degree of hulling in these reliccrops was significantly higher. Clear differences were also identified within the group of the ancient varieties. Einkorn grain was found with the highest degree of hulling, amounting to $29.60 \%$; hulled grains occurred at a slightly lower rate in the emmer wheat sample (20.4\%), while spelt was more effectively purified, the grain with hull accounted for only $5.83 \%$ of the sample (Table 1 ).

Table 1. Commodity characteristics relatedassessment of the grains from the relevant ancient wheats and common wheat of Arkadia cultivar $(\bar{x} \pm \mathrm{SD})$

\begin{tabular}{|c|c|c|c|c|}
\hline Grain characteristic & Einkorn wheat & Emmer wheat & Spelt wheat & Common wheat \\
\hline Moisture content [\%] & $12.04^{\mathrm{b}} \pm 0.17$ & $11.52^{\mathrm{b}} \pm 0.20$ & $10.09^{\mathrm{c}} \pm 0.14$ & $14.05^{\mathrm{a}} \pm 0.18$ \\
\hline Bulk density [kg.h-1 $\left.{ }^{-1}\right]$ & $67.67^{\mathrm{b}} \pm 1.15$ & $67.71^{\mathrm{b}} \pm 1.73$ & $75.05^{\mathrm{a}} \pm 1.73$ & $68.06^{\mathrm{b}} \pm 1.15$ \\
\hline Uniformity [\%] & $26.87^{\mathrm{d}} \pm 0.58$ & $42.07^{\mathrm{c}} \pm 0.74$ & $55.75^{\mathrm{b}} \pm 0.81$ & $92.65^{\mathrm{a}} \pm 0.92$ \\
\hline Plumpness [\%] & $62.43^{\mathrm{c}} \pm 1.15$ & $65.99^{\mathrm{bc}} \pm 0.92$ & $66.98^{\mathrm{b}} \pm 0.87$ & $92.65^{\mathrm{a}} \pm 0.75$ \\
\hline 1000 grain weight [g d.w.] & $23.47^{\mathrm{c}} \pm 0.40$ & $21.70^{\mathrm{c}} \pm 0.35$ & $31.25^{\mathrm{b}} \pm 0.46$ & $38.83^{\mathrm{a}} \pm 0.36$ \\
\hline Degree of hulling [\%] & $29.60^{\mathrm{a}} \pm 0.58$ & $20.38^{\mathrm{b}} \pm 0.52$ & $5.83^{\mathrm{c}} \pm 0.35$ & $0.86^{\mathrm{d}} \pm 0.12$ \\
\hline Glassiness [\%] & $65.00^{\mathrm{b}} \pm 1.15$ & $90.00^{\mathrm{a}} \pm 1.44$ & $30.00^{\mathrm{d}} \pm 0.92$ & $50.00^{\mathrm{c}} \pm 1.27$ \\
\hline
\end{tabular}

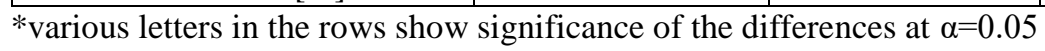




\section{Sieve analysis of the flours}

Distribution of particle sizes in flour indirectly affects its baking quality. Flour with more uniform granularity has better practical and baking characteristics (Dąbkowska 2009, Jurga 2005). There were statistically significant differences in the granulometric composition of the flours in question, relative to the raw material subjected to milling. The exceptions included the particles of $315-265 \mu \mathrm{m}$ size fraction, whose quantities in einkorn and spelt flour were practically the same, as well as $150-132 \mu \mathrm{m}$ size fraction in the case of the flour from emmer and the conventional wheat. The share of the specific fractions was most varied in the einkorn flour, the largest fraction being the particles in the size range of $180-150 \mu \mathrm{m}$ (as much as 62.23 g) (Figure 1). The sieve analysis of the emmer flour showed rather uniform percent shares of the specific fractions in the entire sample, notably however the largest group consisted of the smallest particles sifted through the $132 \mu \mathrm{m}$ sieve. Spelt flour was also quite uniform, but unlike emmer flour, it contained a lower quantity of particles in the range of $315-$ $180 \mu \mathrm{m}$, and more $180-150 \mu \mathrm{m}$ size and mealy fraction particles. The flour from the common wheat of Arkadia cultivar stood out for the very high content of the mealy fraction, i.e. particles below $150 \mu \mathrm{m}$. Furthermore, compared to the other types of flour, the emmer flour was found with the greatest share of the thicker particles with a size over $180 \mu \mathrm{m}$ (39.18 g). Both the thickness and the golden-brown colour of this flour were associated with the high glassiness and hardness of emmer grain. During the milling process the fragile seed coat was crushed and its significant part ultimately ended up in the product. It was found that increasing moisture content during the conditioning process designed to make the seed coat more flexible and to separate it from the endosperm, was ineffective due to the high degree of hulling observed in the emmer grains. In fact, the water-soaked husks made the milling process impossible. Ultimately, the flour obtained in the specific process conditions had high contents of ash, amounting to $1.14 \%$.

\section{Chemical composition of the flours}

Excessive content of moisturein flour promotes activity of enzymes and microorganisms contained in it, which adversely affects its technological value. The contents of water in the relevant flours was varied, ranging from $12.13 \%$ in einkorn flour to $14.78 \%$ in the flour from common wheat of Arkadia cultivar (Table 2). The findings show that there were statistically significant differences in moisture contents between the varieties taken into account, except for the spelt flour and the conventional wheat flour which had similar water content

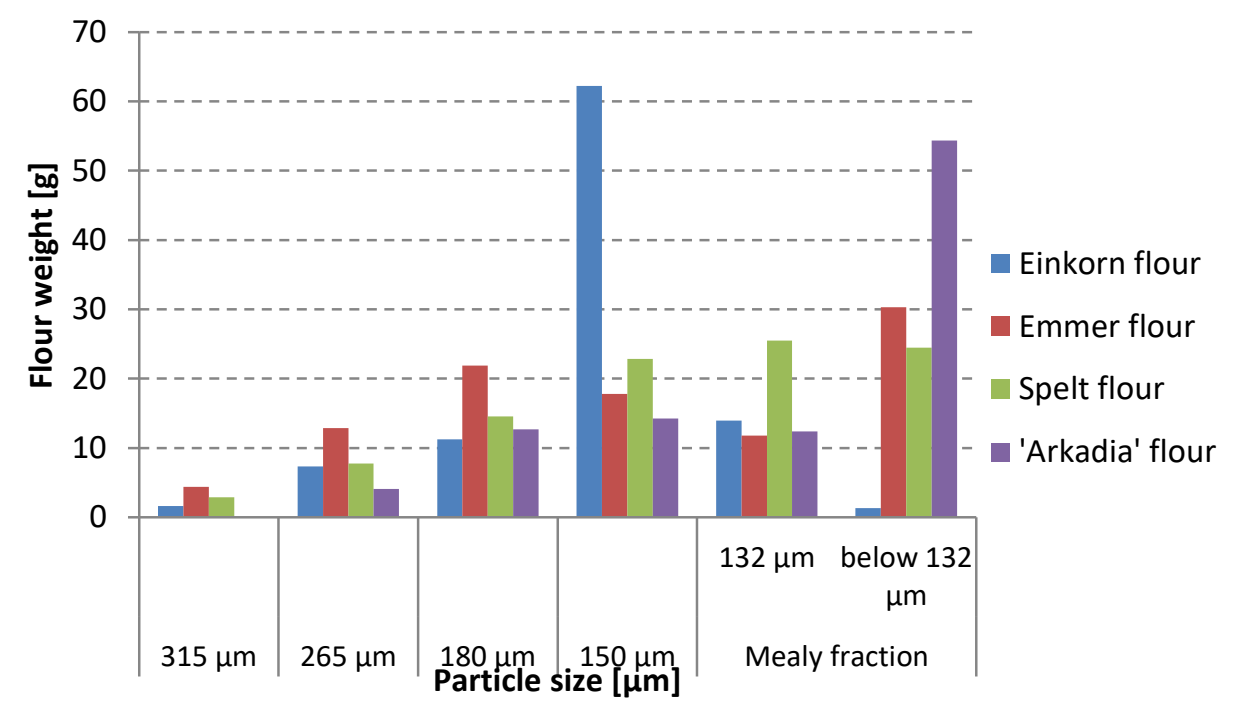

Figure 1. Granulometric composition of the flours

Table 2. Chemical composition of the flours from the grains of ancient wheat varieties and common wheat of Arkadia cultivar $(\bar{x} \pm \mathrm{SD})$

\begin{tabular}{|l|l|l|l|l|}
\hline Component & Einkorn flour & Emmer flour & Spelt flour & Common wheat flour \\
\hline Water [\%] & $12.13^{\mathrm{c}} \pm 0.17$ & $13.92^{\mathrm{b}} \pm 0.14$ & $14.03^{\mathrm{b}} \pm 0.18$ & $14.78^{\mathrm{a}} \pm 0.19$ \\
\hline Total protein (Nx5.7) [\% d.w.] & $22.40^{\mathrm{a}} \pm 0.40$ & $20.80^{\mathrm{b}} \pm 0.35$ & $17.30^{\mathrm{c}} \pm 0.38$ & $13.50^{\mathrm{d}} \pm 0.17$ \\
\hline Damaged starch [\%] & $6.11^{\mathrm{a}} \pm 0.12$ & $5.20^{\mathrm{b}} \pm 0.09$ & $4.48^{\mathrm{c}} \pm 0.10$ & $4.16^{\mathrm{c}} \pm 0.09$ \\
\hline Total ash [\% d.w.] & $1.09^{\mathrm{a}} \pm 0.03$ & $1.14^{\mathrm{a}} \pm 0.02$ & $0.77^{\mathrm{a}} \pm 0.02$ & $0.81^{\mathrm{b}} \pm 0.01$ \\
\hline
\end{tabular}

* various letters in the rows show significance of the differences at $\alpha=0.05$ 
Protein contents of the flours studied were significantly varied, relative to the original raw material, ranging between $22.4 \%$ d.w. in the case of spelt flour and $13.5 \%$ d.w. in the control flour (Table 2). Abdel-Aal et al., (2002) and D'Egidio et al., (1993) examined einkorn flour (70\% extraction) and identified total protein contents in the range of 11.3 - 18.3\% d.w., while Jankowska et al. (2011) reported lower protein contents of $10.5-11.1 \%$ d.w. in flour obtained at a similar $(67 \%)$ extraction rate. Emmer flour was found by Gélinas and McKinnon (2016) to contain $14.2 \%$ of total protein on average. Spelt flours examined by Krawczyk et al. (2008b) contained $13.1-16.4 \%$ of this component in the dry weight. On the other hand, LackoBartošová and Rédlová (2007) reported the values in the range of 14.80-18.55\%, while Sobczyk et al. (2017a) found lower mean protein contents (9.8$13.4 \%$ d.w.) in spelt flours.

The contents of damaged starch in spelt flour and common wheat flour were very similar, amounting to less than $4.5 \%$, contrary to the other types of flour which were found to significantly differ with regard to this parameter. This mainly resulted from the milling process which in the case of the einkorn and emmer grains was more difficult and extended in time. The einkorn flour was found to contain damaged starch grains at a very high rate $(6.11 \%)$, and only slightly lower value of this factor was identified in the emmer flour (5.20\%). Dąbkowska (2009) reported similar contents of damaged starch in selected strains of spring spelt, on average amounting to $4.2 \%$, while the related values identified by Sobczyk et al. (2017c) were in the range of $4.0-5.7 \%$.

There were differences in mean ash contents of flours obtained from grains of ancient wheat varieties as well as common wheat of Arkadia cultivar (Table 2). The einkorn flour and emmer flour did not differ significantly in terms of ash contents which amounted to $1.09 \%$ d.w. and $1.14 \%$ d.w., respectively. Likewise, the spelt flour and the common wheat flour were characterised by similar contents of ash $(0.77 \%$ d.w. and $0.81 \%$ d.w., respectively). The higher ash contents of the einkorn and emmer flours, compared to the remaining flours studied, partly result from the low plumpness of the grains of the former varieties, and a significant share of the coat in the total weight of the samples, and are also associated with the course of the milling process where the bran fraction adds to the total flour extraction. The einkorn flours examined by Lomolino et al. (2017) on average were characterised by ash content of $1.37 \%$, which was higher compared to the values identified in the current study. Spelt flours obtained by Krawczyk et al. (2008a) were found with ash contents in the range of $0.50-0.58 \%$. Similar ash contents of spelt flours were reported by Majewska et al., (2007) and Macaroni et al., (2002); on the other hand, the flours from wheat varieties investigated by Sobczyk et al., (2017a) were found with slightly higher ash contents ranging from 0.54 to $0.78 \%$.

\section{Indirect indicators of flours baking quality}

The content of wet gluten is extremely important for the baking quality of flour because gluten is a binding agent holding together the flour and other ingredients, and ultimately creating the backbone structure of the dough (Bojňanská and Frančáková, 2002). The current findings generally show higher contents of wet gluten in the flours obtained from grain of the ancient wheat varieties (from $39.26 \%$ in einkorn flour to $59.60 \%$ in emmer flour) compared to the common wheat flour $(28.50 \%)$ (Table 3). Lomolino et al. (2017) showed mean wet gluten content of einkorn flour amounting to $17.84 \%$, on the other hand Gélinas and McKinnon (2016) examined chemical composition of emmer flour and reported $39.4 \%$ content of wet gluten. According to Lacko-Bartošova and Rédlova (2007) spelt flour may contain $31.03-39.50 \%$ of wet gluten. Studies carried out by Filipčev et al. (2014) and Krawczyk et al. (2008b) showed the contents of this component in the range from 35.00 to $45.90 \%$. Similar values were reported by Sobczyk et al. (2017b), while Macaroni et al. (2002) and Capuchová (2001) demonstrated approximately $40 \%$ contents of gluten. Furthermore, Bojňanska and Frančákova (2002) showed mean contents of wet gluten in spelt flour to be in the range from 30.60 to as much as $51.80 \%$.

Table 3. Baking quality indicators of the flours from grain of ancient wheat varieties and common wheat of Arkadia cultivar $(\bar{x} \pm \mathrm{SD})$

\begin{tabular}{|l|l|l|l|l|}
\hline Flour characteristic & Einkorn flour & Emmer flour & Spelt flour & Common wheat flour \\
\hline Wet gluten [\%] & $39.26^{\mathrm{c}} \pm 0.81$ & $59.60^{\mathrm{a}} \pm 0.98$ & $46.80^{\mathrm{b}} \pm 0.75$ & $28.50^{\mathrm{d}} \pm 0.58$ \\
\hline Spreadability of gluten [mm] & $17.50^{\mathrm{a}} \pm 0.35$ & $18.50^{\mathrm{a}} \pm 0.46$ & $6.00^{\mathrm{b}} \pm 0.17$ & $8.00^{\mathrm{c}} \pm 0.12$ \\
\hline Gluten number (GN) & $33.86^{\mathrm{a}} \pm 0.46$ & $47.53^{\mathrm{c}} \pm 0.58$ & $75.35^{\mathrm{d}} \pm 0.79$ & $42.18^{\mathrm{b}} \pm 0.52$ \\
\hline Gluten Index & $29.56^{\mathrm{c}} \pm 0.64$ & $31.53^{\mathrm{c}} \pm 0.73$ & $64.16^{\mathrm{b}} \pm 0.95$ & $88.49^{\mathrm{a}} \pm 0.99$ \\
\hline Zeleny sedimentation value $[\mathrm{ml}]$ & $28.00^{\mathrm{c}} \pm 0.42$ & $23.00^{\mathrm{d}} \pm 0.46$ & $35.00^{\mathrm{b}} \pm 0.53$ & $38.00^{\mathrm{a}} \pm 0.52$ \\
\hline Falling number [s] & $352.00^{\mathrm{c}} \pm 5.77$ & $510.00^{\mathrm{a}} \pm 6.93$ & $455.00^{\mathrm{b}} \pm 7.51$ & $297.00^{\mathrm{d}} \pm 5.20$ \\
\hline
\end{tabular}

* various letters in the rows show significance of the differences at $\alpha=0.05$ 
Gluten index for einkorn and emmer flour were similar amounting to 29.56 and 31.53 , respectively (Table 3), while spelt flour was characterised by significantly higher gluten index of 64.14. Conversely, a study by Filipčev et al. (2014) investigated spelt flours and identified the related value to be in the broad range from 36.50 to 86.50 . Slightly different values in the range of 44.00 61.00 and 43.57 - 64.67 were reported respectively by Krawczyk et al. (2008b) and Lacko-Bartošová and Rédlová (2007).

Based on gluten spreadability and gluten number it is possible to assess flour quality and potential use. The flours from einkorn wheat and emmer wheat were characterised by nearly the same, very high spreadability ( $17.5 \mathrm{~mm}$ and $18.5 \mathrm{~mm}$, respectively), while the remaining flours studied differed significantly in terms of this parameter (Table 3 ). The gluten number identified for the two former flours amounted to 33.86 and 47.53, respectively. Flours with gluten spreadability above $12 \mathrm{~mm}$ and GN up to 40 are described as weak flours. These include the einkorn flour investigated in the current study. It can be used in production of delicate dough or batter for sponge cakes or waffles; in other baked products it should be used in combination with strong flours. The einkorn flour investigated by Jankowska et al. (2011) was found with a similar value of gluten number but lower gluten spreadability in the range of $10.2-12 \mathrm{~mm}$. The emmer flour was found to presentmedium baking quality (as a combined effect of high spreadability and good GN). It seems this kind of flour can be used for similar purposes to those proposed above for einkorn flour. Based on the data listed in Table 3 , the spelt flour investigated here can be recognised among strong flours because of the low gluten spreadability $(6.00 \mathrm{~mm})$ and high gluten number (75.35). The flour may be used in yeast dough and as a natural enhancer of wheat flour baking quality. The spelt flour in fact showed better gluten quality parameters compared to the flour from the common wheat of Arkadia cultivar which was characterised by similar gluten spreadability $(8.00 \mathrm{~mm})$, but significantly lower gluten number (42.18) and consequently was defined as good flour, to be used mainly in small baked products, such as bread rolls. A study carried out by Rachoń et al., (2011) showed spelt gluten spreadability of $4-4.4 \mathrm{~mm}$, while Achremowicz et al., (1999) reported the related values in the range of $8.7-9.8 \mathrm{~mm}$. Significantly higher spreadability of spelt flour gluten, in the range of $13.00-15.66 \mathrm{~mm}$ and $13.00-18.33 \mathrm{~mm}$, was shown in studies by Lacko-Bartošova and Rédlova (2007) and Bojňanska and Frančákova (2002), respectively.
Zeleny sedimentation value describes structure formation properties of flour. A higher value of this parameter corresponds to a higher content of gluten protein, particularly glutenin which is responsible for the baking quality of the flour (Dąbkowska 2009). The einkorn flour and emmer flour were characterised by low protein swelling capacity $(28.00 \mathrm{ml}$ and $23.00 \mathrm{ml}$, respectively); this factor in combination with the very high spreadability and relatively low gluten index negatively affected the baking quality of these types of flour (Table 3). Studies carried out by Jankowska et al. (2011) and Abdel-Aal et al. (1997) reported even lower sedimentation index for einkorn flour, in the range of $9.10-10.60 \mathrm{ml}$. The current study showed very similar sedimentation indexes for the spelt flour $(35.00 \mathrm{ml})$ and the conventional wheat flour $(38.00$ $\mathrm{ml}$ ), however the statistical analysis proved that the difference between these was significant. The related findings for spelt flour reported in the literature are greatly varied. Majewska et al. (2007) showed values in the range of 12.00-27.00 ml, Sobczyk et al. (2017a) reported findings between 15.00 and $27.00 \mathrm{ml}$, compared to $18.00-38.00 \mathrm{ml}$ identified by Zanetti et al. (2001). According to Lacko-Bartošova and Rédlova (2007) Zeleny' s value for flours from this ancient wheat variety is higher, ranging from 26.67 to $35.33 \mathrm{ml}$. Similar values were identified by Bojňanská and Frančáková (2002). Even higher sedimentation indexes between 30.00 and $40.00 \mathrm{ml}$, or amounting to $42.00 \mathrm{ml}$, or in the range of 34.40 do $50.20 \mathrm{ml}$ were reported in their respective studies by Krawczyk et al. (2008b), Macaroni et al. (2002) and Filipčev et al. (2014).

The falling number is a parameter indirectly describing the baking quality of flour; the related test assesses activity of amylolytic enzymes, mainly $\alpha$-amylase, which hydrolyse starch. The flours taken into account in this study were varied in terms of the falling number which ranged from $297 \mathrm{~s}$ in the case of the control flour to $510 \mathrm{~s}$ in the flour obtained from emmer wheat (Table 3 ).

The optimum range of the falling number is defined as $200-350 \mathrm{~s}$ (Knapowski et al. 2015, Krawczyk et al. 2008b).The high falling numbers identified in emmer flour and spelt flour reflect low activity of amylolytic enzymes. Effectiveness of this type of flour for baking purposes may be improved by prolonged dough fermentation, or by addition of enzyme-based dough improvers, and sugar, if practicable in the specific baked product. Jankowska et al. (2011) in the case of flour from einkorn wheat identified the falling number in the range of 334-365 s. There are many research reports presenting results of falling number tests in spelt 
flours and the evidence indicates medium or low activity of amylolytic enzymes. The study carried out by Krawczyk et al. (2008b) showed the falling number between 270 and $331 \mathrm{~s}$, similar values (288$343 \mathrm{~s}$ ) were reported by Achremowicz et al. (1999), while the flours investigated by Sobczyk et al. (2017c), Bojňanska and Frančákova (2002), Macaroni et al. (2002) and Abdel-Aal et al. (1997) were found with the relevant value in the broad range from 285 to $445 \mathrm{~s}$.

\section{CONCLUSIONS}

The study investigated ancient wheat varieties, and showed that einkorn and emmer present significant similarities as regards commodity characteristics of the grain and baking quality of the flour, and generally their properties were inferior to those of spelt and common wheat of Arkadia cultivar. The indirect baking quality indicators show that einkorn flour and emmer flour can be used for baking, however they present low technological value. The findings show that,out of all the ancient wheat varieties investigated, emmer has the poorest properties (which is reflected by the low values of gluten number, Zeleny's index, GI, and high spreadability). Technological usefulness of the relic crops results from such factors as the high total protein contents (the highest in einkorn), as well as organoleptic properties of the products, including the taste and flavour characteristic to each variety, as well as the interesting colour in the case of einkorn flour. However, due to the weak structure of the gluten network, the einkorn and emmer dough may not be easy to manage. The spelt grain and flour were characterised by the best parameters matching those identified in the common wheat of medium technological value. Given the specific pleasant taste and flavour, as well as colour in the case of einkorn, products from ancient wheat varieties are an interesting addition to the assortment of baked goods on offer in bakeries, restaurants and agritourist farms.

\section{REFERENCES}

1. Abdel-Aal E.S.M. \& Hucl P. 2002. Amino acid composition and in vitro protein digestibility of selected ancient wheats and their and products. Journal of Food Composition and Analysis, 6(15): 737-747. doi.org/10.1006/jfca.2002.1094

2. Abdel-Aal E.S.M., Hucl P., Sosulski F.W. \& Bhirud P.R. 1997. Kernel, milling and baking properties of spring - type spelt and einkorn wheats. Journal of Cereal Science, 3(26): 363-370. doi.org/10.1006/jcrs.1997.0139

3. Achremowicz B., Kulpa D. \& Mazurkiewicz J. 1999. Technologiczna ocena ziarna pszenic orkiszowych. Zeszyty Naukowe AR Kraków, 360: 11-17.

4. Bojňanská T. \& Frančáková H. 2002. The use of spelt wheat (Triticum spelta L.) for baking applications. Rostlinná Výroba, 48(4): 141-147.

5. Cacak - Pietrzak G., Gondek E. \& Jończyk K. 2013. Porównanie struktury wewnętrznej oraz właściwości przemiałowych ziarna orkiszu i pszenicy zwyczajnej z uprawy ekologicznej. Zeszyty Problemowe Postępów Rolniczych, 574: 3-10.

6. Cacak - Pietrzak G. \& Gondek E. 2010. Właściwości przemiałowe ziarna orkiszu i pszenicy zwyczajnej. Acta Agrophysica, 16(2): 263-273.

7. Capuchová I. 2001. Technological quality of spelt (Triticum spelta L.) from ecological growing system. Scientia Agriculturae Bohemica, 32: 307-322.

8. Christopher A., Sarkar D., Zwinger S. \& Shetty K. 2018. Ethnic food perspective of North Dakota Common Emmer Wheat and relevance for health benefit targeting type 2 diabetes. Journal of Ethnic Food, 5: 66-74. doi.org/10.1016/j.jef.2018.01.002

9. Coda R., Rizzello C. G., Trani A. \& Gobbetti M. 2011. Manufacture and characterization of functional emmer beverages fermented by selected lactic acid bacteria. Food Microbiology, 28: 526-536. doi.org/10.1016/j.fm.2010.11.001

10. Dąbkowska E. 2009. Wpływ odmiany ziarna orkiszu uzyskanego w warunkach produkcji ekologicznej na jakość mąki. Praca doktorska przygotowana na Wydziale Nauki o Żywności Uniwersytetu Warmińsko Mazurskiego w Olsztynie.

11. Degaonkar A.M., Tomhankar S.A. \& Rao V.S. 2005. Anassessment of cultivated emmer germplasm for gluten proteins. Euphytica, 145: 49-55. DOI: 10.1007/s10681-005-0142-5 
12. D'Egidio M.G., Nardi S. \& Vallega V. 1993. Grain, flour, and dough characteristics of selected strains of diploid wheat, Triticum monococcum L. Cereal Chemistry, 3(70): 298-303.

13. Ertop M.H. 2019. Comparison of industrial and homemade bulgur producted from einkorn wheat (Triticum monococcum) and durum wheat (Triticum durum): Physicochemical, nutritional and microtextual properties. Journal of Food Processing and Preservation, 43e13863: 1-8. DOI: 10.1111/jfpp.13863

14. FAOSTAT (2017). Crop Statistics. Retrieved: 10 June 2020, from: http://www.fao.org/faostat/en/\#data/QC.

15. Filipčev B., Šimurina O. \& Bodroža - Solarov M. 2014. Combined effect of xylanase, ascorbic and citric acid in regulating the quality of breadmade from organically grown spelt cultivars. Journal of Food Quality. 37: 185-195. 10.1111/jfq.12081

16. Gélinas P. \& McKinnon C. 2016. Gluten weight in ancient and modern wheat and the reactivity of emtopestowards R5 and G12 monoctonel antibodies. International Journal of Food Science and Technology, 51: 1801-1810. doi:10.1111/ijfs.13151

17. Haber T., Horubałowa A. 1975. Analiza techniczna w przetwórstwie zbożowym. Wydawnictwo Szkolne i Pedagogiczne, Warszawa 1975.

18. Horubałowa A., Haber T. 1975. Analiza techniczna w piekarnictwie. Wydawnictwo Szkolne i Pedagogiczne, Warszawa 1975.

19. ICC, 1994. International Association For Cereal Science And Technology (ICC) Standard Method No. 116/1. Determination of sedimentation value (Ac. to Zeleny) as an approximate measure of baking quality. ICC Secretariat, Vienna.

20. ICC, 1994. International Association for Cereal Science and Technology (ICC) Standard Method No. 155. Determination of wet gluten quantity and quality of whole wheat meal and wheat flour. ICC Secretariat, Vienna.

21. ICC, 1995. International Association for Cereal Science and Technology (ICC) Standard Method No.107/1. Determination of the "falling number" according to Hagberg-Perten as a measure of the degree of alpha-amylase activity in grain and flour. ICC Secretariat, Vienna.

22. Hidalgo A., Lucisano M., Mariotti M. \& Brandolini A. 2019. Physico - chemical and nutritional characteristics of einkorn flour cookies. Journal of Food Processing and Preservation, e14079: 1-8. DOI: 10.1111/jfpp.14079

23. Hidalgo A. \& Brandolini A. 2017. Nitrogen fortilisation effects on technological parameters and carotenoid, tocol and phenolic acid content of einkorn (Triticum monococcum L. subsp. monococcum): A two-year evaluation. Journal of Cereal Science,73:18-24. doi.org/10.1016/j.jcs.2016.11.002

24. Jankowska M., Kędzior Z., Pruszka - Kędzior A., Chojnacka E. \& Binder M. 2011. Porównanie właściwości funkcjonalnych glutenu z pszenicy samopszy i pszenicy zwyczajnej. ŻYWNOŚĆ. Nauka. Technologia. Jakość., 6 (79): 79-90.

25. Jurga R. 2005. Wpływ stopnia rozdrobnienia (granulacji) maki na jej właściwości wypiekowe. Przegląd Zbożowo-Młynarski, 12: 13.

26. Knapowski T., Kozera W., Murawska B., Wszelaczyńska E., Pobereżny J., Mozolewski W. \& Keutgen A. 2015. Ocena parametrów technologicznych wybranych odmian pszenicy ozimej pod względem wypiekowym. Inżynieria i Aparatura Chemiczna, 54(5): 255-256.

27. Kraska P., Andruszczak S., Dziki D., Stocki M., Stocka N., Kwiecińska - Poppe E., Różyło K. \& Gierasimiuk P. 2019. Green grain of spelt (Titicum aestivum ssp. spelta) harvested and the stage of milk - dough as a rich source of valuable nutrients. Emirates Journal of Food and Agriculture, 31(4): 263-270. doi.org/10.9755/ejfa.2019.v31.i4.1931

28. Krawczyk P., Ceglińska A. \& Izdebska K. 2008a. Porównanie właściwości reologicznych ciasta i jakości pieczywa otrzymanego z mąki orkiszu i pszenicy zwyczajnej. ŻYWNOŚĆ. Nauka. Technologia. Jakość., 4 (59): 141-151.

29. Krawczyk P., Ceglińska A. \& Kardialik J. 2008b. Porównanie wartości technologicznej ziarna orkiszu z pszenicą zwyczajną. ŻYWNOŚĆ. Nauka. Technologia. Jakość., 5 (60): 43-51.

30. Lacko - Bartošová M. \& Rédlová M. 2007. The significance of spelt wheat cultivated in ecological farming in the Slovak Republic. Proceeding of conference „Organic Farming 2007”, 79-81.

31. Lomolino G., Morari F., Dal Ferro N., Vincenzi S. \& Pasini G. 2017. Investigating the einkorn (Triticum monococcum) and common wheat (Triticum aestivum) bread rumb structure with X-ray microtomography 
effects on rheological and sensory properties. International Journal of Food Science and Technology, 52: 1498-1507. doi:10.1111/ijfs.13425

32. Macaroni E., Carcea M., Schiavone M. \& Cubadda R. 2002. Spelt (Triticum spelta L.) pasta quality: combined effect of flour properties and drying conlitions. Cereal Chemistry, 79: 634-639. doi.org/10.1094/CCHEM.2002.79.5.634

33. Majewska K., Dąbkowska E., Żuk - Gołaszewska K. \& Trybulski J. 2007. Wartość wypiekowa mąki otrzymanej z ziarna wybranych odmian orkiszu (Triticum spelta L.). ŻYWNOŚĆ. Nauka. Technologia. Jakość., 2(25): 60-71.

34. PN-EN ISO 712:2012. Ziarno zbóż i przetwory zbożowe - Oznaczanie wilgotności - Metoda odwoławcza.

35. PN-EN ISO 7971-3:2019-03. Ziarno zbóż - Oznaczanie gęstości w stanie zsypnym, zwanej masą hektolitra - Część 3: Metoda rutynowa.

36. PN-EN ISO 2171:2010. Ziarno zbóż, nasiona roślin strączkowych i ich przetwory - Oznaczanie zawartości popiołu metodą spalania.

37. PN-EN ISO 21415-1:2007. Pszenica i mąka pszenna - Zawartość glutenu - Część 1. Oznaczanie ilości glutenu mokrego metodą ręcznego wymywania.

38. PN-EN ISO 21415:2015-12. Pszenica i mąka pszenna - Zawartość glutenu - Część 2. Oznaczanie ilości glutenu mokrego i indeksu glutenu za pomocą urządzeń mechanicznych.

39. Rachoń L., Szumidło G. \& Stankowski S. 2011. Porównanie wybranych wyróżników wartości technologicznej pszenicy zwyczajnej (Triticum aestivum ssp. vulgare), twardej (Triticum durum) i orkiszowej (Triticum aestivum ssp. spelta). Fragmenta Agronomica, 28 (4):52-59.

40. Radomski G., Bać A. \& Mierzejewska S. 2007. Ocena porównawcza wartości wypiekowej mąki pszennej i orkiszowej. Inżynieria Rolnicza. 5(93): 369-374.

41. Rożnowski J., Kłosowska J. \& Polzer P. 2015. Żywieniowe i prozdrowotne znaczenie pszenicy orkisz (Triticum spelta L.). Postęy Fitoterapii, (16) 1:45-49.

42. Sawicka B. \& Krochmal - Marczak B. 2012. Pszenica orkiszowa (Triticum aestivum ssp. spelta) jako alternatywa dla gospodarstw ekologicznych. W: Współczesne dylematy polskiego rolnictwa, część II .PWS JPII, Biała Podlaska, 344-357.

43. Sobczyk A., Pycia K. \& Jaworska G. 2017a. Charakterystyka porównawcza wartości technologicznej ziarna starych odmian i nowych rodów orkiszu (Triticum spelta L.) oraz ziarna pszenicy zwyczajnej (Triticum vulgare). Zeszyty Problemowe Postępów Nauk Rolniczych, 598: 81-91. DOI 10.22630/ZPPNR.2017.589.23

44. Sobczyk A., Pycia K., Stankowski S., Jaworska G. \& Kuźniar P. 2017b. Evaluation of the rheological properties of dough and quality of breadmade with the flour obtained from old cultivars and modern breeding lines od spelt (Triticum aestivum ssp.spelta). Journal od Cereal Science, 77: 35-41. doi.org/10.1016/j.jcs.2017.07.013

45. Sobczyk A., Pycia K., Jaworska G. \& Kaszuba J. 2017c. Comparison of fermentation strength of the flours obtained from the grain of old varieties and modern breeding lines of spelt (Triticum aestivum ssp. spelta). Journal of Food Processing and Preservation, 41e13293: 1-6. DOI: 10.1111/jfpp.13293

46. Waga J., Węgrzyn S., Boros D. \& Cygankiewicz A. 2002. Wykorzystanie orkiszu (Triticum aestivum ssp. spelta) do poprawy właściwości odżywczych pszenicy zwyczajnej (Triticum aestivum ssp. vulgare). Biuletyn IHAR, 221; 3-16.

47. Zanetti S., Winzeler M., Feuillet C., Keller B. \& Messer M. 2001. Genetic analysis of bread-making quality in wheat and spelt. Plant Breeding, 120: 13-19. doi.org/10.1046/j.1439-0523.2001.00552.x 